\title{
JAVNOBILJEŽNIČKI RAZVOD BRAKA U REFORMIRANOM SLOVENSKOM PRAVU
}

Sažetak: Razvod braka pred notarima latinskoga tipa kao alternativan onom sudskom, prisutan je na europskom kontinentu od početka 2000-ih godina. Oblici takvog razvoda braka prvo su se javili u istočnoeuropskim državama. Od 2015., međutim, bilježi se propisivanje nadležnosti notara za sporazumni razvod braka $i$ u državama zapadne i južne Europe. Posljednja među europskim državama koja je propisala sporazumni razvod braka pred javnim bilježnicima je Slovenija, u sklopu reforme obiteljskog $i$ izvanparničnog prava i postupka.

Utom kontekstu, u radu se raspravlja o novinama i temeljnim načelima obiteljskih sudskih postupaka u reformiranom slovenskom pravu. Posebni dio rada sadrži analizu sporazumnog razvoda braka pred slovenskim javnim bilježnicima. Razlog odabira tog pravnog sustava je u istom ishodištu razvoja s hrvatskim, sličnosti tih dvaju pravnih sustava, kao i okolnosti da u tim srednjoeuropskim državama članice EU-a, reformska nastojanja u jednoj najčešće slijede reforme i postignute rezultate u drugoj. Potom slijedi analiza i rasprava o javnobilježničkom razvodu braka iz hrvatske perspektive, posebice o okolnostima koje bi se trebale uzeti u obzir pri promišljanju njegova reguliranja, u cilju aktualizacije i postizanja istaknutih prednosti. U zaključnom dijelu rada sadržana su neka razmišljanja autora i njegove projekcije, de lege ferenda, za hrvatsko uređenje, ali i država u njezinu okruženju.

Ključne riječi: $\quad$ razvod braka, javni bilježnik, postupak, slovensko pravo 


\section{UVOD: ODREĐENJE PREDMETA ISTRAŽIVANJA}

Razvod braka pred notarima latinskoga tipa ${ }^{1}$ kao alternativan onom sudskom, prisutan je na europskom kontinentu od početka 2000-ih godina. Oblici takvog razvoda braka prvo su se javili u istočnoeuropskim državama. Prvo je Estonija, izmjenama i dopunama propisa o notarima, registraciji osobnih stanja i obiteljskih propisa 2009., propisala ovlasti notara na području sklapanja i razvoda braka. ${ }^{2}$ Prema estonskom uređenju, ako je riječ o sporazumnom razvodu braka, on je dopušten na temelju prijedloga za sporazumni razvod braka pred notarom. Bračni drugovi trebaju potvrditi da nemaju spora u odnosu na uvjete i posljedice razvoda braka. ${ }^{3}$ Sporazumni razvod braka pred notarima dopušten je i u Latviji ${ }^{4}$ i Rumunjskoj, ${ }^{5}$ također, i u slučajevima razvoda braka bračnih drugova s maloljetnom djecom. Propisane pretpostavke takvih oblika razvoda braka bračnih drugova sa zajedničkom maloljetnom djecu su sporazum bračnih drugova o pitanjima roditeljske skrbi, ostvarivanja osobnih odnosa i uzdržavanja djeteta. ${ }^{6}$ Posebnost je rumunjskog uređenja i u ovlastima notara da zatraže izvješće od nadležnih skrbničkih tijela u odnosu na sporazum bračnih drugova o pitanjima roditeljske skrbi, kao i u obvezi da omoguće djetetu izražavanje mišljenja. ${ }^{7}$

Promatrajući opisane oblike razvoda braka istočnoeuropskih država te kompetencije njihovih notara latinskoga tipa, treba uzeti u obzir specifičnosti razvoja pravnih sustava tih država. Riječ je o bivšim državama socijalističkoga uređenja za vrijeme kojega su notari bili transfor-

1 O načelima slobodnog notarijata latinskoga tipa i drugim oblicima notarske službe u Europi v. više u: Zimmermann, S.; SchmitzVornmoor, A., Javnobilježnička služba u Europskoj uniji. Filozofija struke i trendovi razvoja, harmonizacija i ujednačavanje, Zbornik Pravnog fakulteta u Zagrebu, vol. 59, br. 6, 2009., str. 1219.-1225. i slj. O povijesnom razvoju europskoga latinskoga javnog bilježništva v. i Dika, M., Osvrt na povijesni razvoj europskoga latinskoga javnog bilježništva, u: Crnić, I.; Dika, M., Zakon o javnom bilježništvu, Organizator, Zagreb, 1994., str. 29.-40.

2 Vidjeti čl. 29. Zakona o notarima Estonije (Riigi Teataja, I 2000, 104, 684), nakon izmjena i dopuna (Riigi Teataja, I 2009, 27, 164), s posljednjim izmjenama i dopunama (Riigi Teataja, I 2019, 8), https://www.riigiteataja.ee/en/eli/ee/506012020001/ consolide/current. Pristupljeno 18. lipnja 2020. Vidjeti čl. 641 Obiteljskoga zakona Estonije (Riigi Teataja, I 2009, 60, 395), s posljednjim izmjenama i dopunama (Riigi Teataja, I 2017, 1), https://www.riigiteataja.ee/en/eli/ee/507022018005/consolide/ current. Pristupljeno 18. lipnja 2020. (u daljnjem tekstu: EObZ) u vezi s čl. 3. st. 8. Zakona o registraciji osobnih stanja Estonije (Riigi Teataja, I 2009, 30, 177), s posljednjim izmjenama i dopunama (Riigi Teataja, I 2019, 3), https://www.riigiteataja.ee/en/ eli/ee/504022014001/consolide/current. Pristupljeno 18. lipnja 2020. (u daljnjem tekstu: EZROS).

3 Vidjeti čl. 64¹.st. 1., čl. 65. st. 2. EObZ-a.

4 Vidjeti čl. 65., čl. 325.-čl. 339. Zakona o notarima Latvije (Latvijas Vēstnesis, 48, 9. srpnja 1993.), s posljednjim izmjenama i dopunama od 14. studenog 2019. (Latvijas Vēstnesis, 240), https://likumi.lv/ta/en/en/id/59982. Pristupljeno 19. lipnja 2020. (u daljnjem tekstu: LZN). Vidjeti čl. 69. Građanskog zakonika Latvije (Valdības Vēstnesis, 41, 20. veljače 1937.), s posljednjim izmjenama i dopunama od 5. prosinca 2019. (Latvijas Vēstnesis, 246), https://likumi.lv/ta/en/en/id/225418-the-civil-law. Pristupljeno 19. lipnja 2020. (u daljnjem tekstu: LGZ).

5 Vidjeti čl. 375.-čl. 378. Zakona br. 287/2009 - Građanskoga zakonika Rumunjske (Monitorul Oficial al României, 511/2009), s posljednjim izmjenama i dopunama (Zakon br. 71/2011, Monitorul Oficial al României, 427/2011, 489/2011), http://legislatie. just.ro/Public/DetaliiDocument/175630. Pristupljeno 19. lipnja 2020. (u daljnjem tekstu: RGZ).

6 Za Latviju v. čl. 325. LZN-a; čl. 77. LGZ-a. Za Rumunjsku v. čl. 375. st. 2. RGZ-a.

7 Vidjeti čl. 264. i čl. 375. st. 2. RGZ-a. O tome v. i Crăciun, N., The Divorce by the Public Notary. Proceedings, Bulletin of the Transilvania University of Braşov, Series VII: Social Sciences, Law, vol 7(56), br. 2, 2014., str. 193.; Frîntu, V-M.; Gherghe, E-R., Divorce through the Spouses' Agreement by Administrative Method or Notarial Procedure, Advances in Fiscal, Political and Law Science, 2013., str. 186., http://www.wseas.us/e-library/conferences/2013/Brasov/EPLS/EPLS-30.pdf. Pristupljeno 19. lipnja 2020.; Papa, A. D.; Tăpuş, I. F., Notary Procedure and Judicial Procedure for the Divorce with Spouses' Agreement, Challenges of the Knowledge Society. Private Law, 2013., str. 346., http://cks.univnt.ro/uploads/cks-2013-articles/index.php?dir=1-Juridical_ Sciences\%2F\&download=cks-2013-law-art-041.pdf. Pristupljeno 19. lipnja 2020. 
mirani u tzv. državne notare. ${ }^{8}$ Tu treba istaknuti i okolnost da u nekima od njih (Estonija, Rumunjska), uz nadležnost notara, postoji i nadležnost registarskih tijela osobnoga stanja za sporazumni razvod braka (tzv. administrativni razvod braka). ${ }^{9}$

Od 2015., međutim, bilježi se propisivanje nadležnosti notara za sporazumni razvod braka i u državama zapadne i južne Europe (Španjolska, ${ }^{10}$ Francuska, ${ }^{11} \mathrm{Grčka}^{12}$ ). Osnovna je karakteristika španjolskog postupka radi razvoda braka pred notarima u tome da je on rezerviran za bračne drugove koji se žele sporazumno razvesti u onim slučajevima u kojima nemaju zajedničke maloljetne djece nad kojoj ostvaruju roditeljsku skrb, a time i potrebe odlučivanja o pitanjima roditeljske skrbi. ${ }^{13}$ Francusko je rješenje specifično budući da ono predviđa ovaj oblik razvoda braka i u onim slučajevima ako sporazum roditelja obuhvaća pitanja koja se odnose na maloljetnu djecu i izrijekom uključuje izjavu da je dijete bilo informirano o svojem pravu da bude saslušano od strane suca, kao i da dijete ne želi ostvarivati to svoje pravo. ${ }^{14}$ Također, prema grčkom uređenju, sporazumni razvod braka pred notarima dopušten je i u slučaju bračnih drugova s maloljetnom djecom. Ako bračni drugovi imaju maloljetnu djecu, oni se moraju sporazumjeti o roditeljskoj odgovornosti, ostvarivanju osobnih odnosa i uzdržavanju djeteta. ${ }^{15}$

$8 \quad$ O transformaciji notara u tzv. državne notarijate te reformskim nastojanjima bivših socijalističkih država v. više u: Woschnak, K., Javnobilježnička reforma u Srednjoj Europi od 1989. do 1995. iz austrijske perspektive, Javni bilježnik, br. 39, 2013., str. 9.-16.

9 Za Estoniju v. čl. 64. EObZ-a i čl. 44. - čl. 49. EZROS-a. Za Rumunjsku v. čl. 375. st. 1. RGZ-a. O tzv. administrativnom razvodu braka država bivšeg socijalističkog uređenja, ali i nordijskih država, kao i njegovu širenju v. više u: Antokolskaia, M., Divorce law in a European perspective, u: Scherpe, J. M. (ur.), European Family Law, Volume III, Family Law in a European Perspective, Edward Elgar Publishing, Cheltenham/Northampton, 2016., str. 60.-64., 67., 72.-79.; Aras Kramar, Slađana, The transformation of divorce procedure in Europe, Familia, Il diritto della famiglia e delle successioni in Europa, br. 3, 2018., str. 280., 287.-294.

Vidjeti čl. 54. Zakona o notarima Španjolske od 28. svibnja 1862., izmijenjen i dopunjen Zakonom br. 15/2015 o dobrovoljnoj sudbenosti od 2. srpnja 2015. (Boletín Oficial del Estado, br. 158/2015), http://iuscomparatum.info/wp-content/ uploads/2015/07/Boletin-Oficial-del-Estado-Viernes-3-de-julio-de-2015. pdf. Pristupljeno 19. lipnja 2020. (u daljnjem tekstu: ŠZN).

11 Vidjetičl.50.ičl.114.st.V.Zakonabr.1547od18.studenoga2016.o modernizacijipravosuđau21.stoljeću,https://www.legifrance. gouv.fr/affichLoiPreparation.do?idDocument=JORFDOLE000030962821\&type=general\&typeLoi=proj\&legislature=14 Pristupljeno 19. lipnja 2020.; v. i čl. 229. Građanskoga zakonika Francuske, u verziji od 14. veljače 2020., https://www.legifrance. gouv.fr/affichCode.do?cidTexte= LEGITEXT000 006070721. Pristupljeno 19. lipnja 2020. (u daljnjem tekstu: FGZ).

12 Vidjeti Zakon br. 4509/2017, čl. 22. (GG A 201, 22. prosinca 2017.), kojim su izmijenjeni čl. 1438. i čl. 1441. Građanskoga zakonika Grčke (u daljnjem tekstu: GGZ). Vidjeti i Rozou, A., Divorce by Mutual Consent in Greece, 29. veljače 2020., https:// www.nomikosodigos.info/en/articles/902-mutual-consent-divorce. Pristupljeno 23. lipnja 2020.; Charakopoulou, D., Divorce, 5. ožujka 2019., http://www.greeklawdigest.gr/topics/aspects-of-greek-civil-law/item/216-divorce. Pristupljeno 23. lipnja 2020.

13 Vidjeti čl. 54. ŠZN-a. Vidjeti i Baos, C., Divorce in Spain before a notary. Legal advice for expatriates. International Law, 2018., https:// www.white-baos.com/en/divorce-in-spain-before-a-notary-legal-advice-for-expatriates-international-law.html. Pristupljeno 23. lipnja 2020.; Spanish Solutions, Divorce at a Spanish Notary, 1. kolovoza 2017., https://www.spanishsolutions.net/blog/ legal-issues-in-spain/new-law-it-is-now-sometimes-possible-to-divorce-at-a-spanish-notary-not-in-court/. Pristupljeno 23. lipnja 2020.

14 Vidjeti čl. 229.-2. i čl. 229.-3. st. 2. t. 6. FGZ-a. O saslušanju djeteta pred sucem u francuskom sustavu v. čl. 388-1. FGZ-a. V. i Notaries of France, What procedure in case of a divorce in France?, 4. srpnja 2020., https://www.notaires.fr/en/couple-family/ differents-types-divorce. Pristupljeno 23. lipnja 2020.; Eskenazi, D.; Brown, C.; Mitchell, I.; Morley, J. D., The New Divorce by Mutual Consent in France: Recognition and Risks of Post-Divorce Litigation in Common-Law Countries: The Examples of England and the United States, 2017., https://www.familylawweek.co.uk/site.aspx?i=ed177705. Pristupljeno 23. lipnja 2020.; za model sporazuma bračnih drugova pred notarom v. i Divorce France, Example of an amicable divorce agreement, 2017., https://www. divorcefrance.fr/types-de-divorce/modele-de-convention-divorce-amiable/. Pristupljeno 23. lipnja 2020.

15 Treba istaknuti vremensko ograničenje sporazuma o roditeljskoj odgovornosti, ostvarivanju osobnih odnosa i uzdržavanju djeteta. Taj sporazum vrijedi najmanje dvije godine (čl. 1441. st. 2. GGZ-a). Uzimajući u obzir potrebu prilagodbe novonastalim okolnostima, roditelji se mogu ponovno sporazumjeti o pitanjima roditeljske odgovornosti. Charakopoulou, op. cit. u bilj. 12. 
Posljednja među europskim državama koja je propisala sporazumni razvod braka pred javnim bilježnicima (koji pripadaju vrsti notara latinskoga tipa) ${ }^{16}$ je Slovenija, donošenjem novog Družinskog zakonika 2017. godine. ${ }^{17}$ Kao i u slučaju španjolskoga uređenja, prihvaćen je pristup prema kojem je ovaj oblik razvoda braka pred javnim bilježnicima dopušten u slučaju sporazuma bračnih drugova koji nemaju zajedničku maloljetnu djecu. ${ }^{18}$

Javljanje i širenje kompetencija javnih bilježnika za sporazumni razvod braka može se promatrati u sklopu tendencija dejudicijalizacije, jačanja stranačke autonomije i privatizacije toga područja obiteljskog prava i postupka. ${ }^{19}$ Ono također zauzima mjesto i u sklopu rasprava o modernizaciji pravosuđa. ${ }^{20}$ Tomu treba pridodati i potrebu rasterećenja pravosuđa, ${ }^{21}$ okolnosti da sudski postupak, posebice parnični postupak, treba biti rezerviran za sporne stvari, adjudikativnu funkciju, odnosno "suđenje". ${ }^{22}$ Može se očekivati da će ovo potonje, tema rasterećenja pravosuđa, u narednom razdoblju i reformskim nastojanjima u Hrvatskoj, ali i u drugim državama u neposrednom okruženju, biti pod povećalom zbog posljedica epidemije uzrokovane COVID-19 virusom. U prvom redu treba istaknuti odgode sudskih postupaka koji su već bili u tijeku, ali i očekivani, veći broj novih sudskih postupaka.

U tom kontekstu, u radu se raspravlja o novinama i temeljnim načelima obiteljskih sudskih postupaka u reformiranom slovenskom pravu (v. infra ad 2.). Posebni dio rada sadrži analizu sporazumnog razvoda braka pred slovenskim javnim bilježnicima (v. infra ad 3.). Razlog odabira tog pravnog sustava je u istom ishodištu razvoja s hrvatskim, sličnosti tih dvaju pravnih sustava, kao i okolnosti da u tim srednjoeuropskim državama članice EU-a, reformska nastojanja u jednoj najčešće slijede reforme i postignute rezultate u drugoj. Tomu treba pridodati i okolnost da je Slovenija posljednja europska država u nizu koja je propisala nadležnost javnih bilježnika za sporazumni razvod braka. Potom slijedi analiza i rasprava javnobilježničkog razvoda braka iz hrvatske perspektive, posebice o okolnostima koje bi se trebale uzeti u obzir pri promišljanju njegova reguliranja, u cilju aktualizacije i postizanja istaknutih prednosti (v. infra ad 4.). U zaključnom dijelu rada sadržane su neka razmišljanja autora i njegove projekcije, de lege ferenda, za hrvatsko uređenje, ali i država u njezinom okruženju (v. infra ad 5.).

16 U nastavku rada korist će se pojam javni bilježnik koji je prihvaćen u hrvatskom pravnom sustavu te opisuje vrstu tzv. latinskoga notarijata.

17 Družinskizakonik(DZ), Uradni list RS, br. 15/2017, 21/2018 - Zakono nevladnih organizacijah (ZNOrg), 22/2019, 67/2019-Zakon o spremembah in dopolnitvah Zakona o matičnem registru (ZMatR-C), http://www.pisrs.si/Pis.web/pregledPredpisa?id=ZAKO7556. Pristupljeno 23. lipnja 2020. (u daljnjem tekstu: DZ).

18 Vidjeti čl. 97. DZ-a te infra ad 3.

19 O braku s aspekta društvene kontrole te, s druge strane, autonomije v. Freeman, M., Family Values and Family Justice, u: Family Values and Family Justice, Ashgate, Farnham/Burlington, 2010., str. 8.-9. i slj. Za rasprave o tzv. kontraktualizaciji obiteljskog prava v. Ponjavić, Z., Porodično pravo od institucije do ugovora, u: Zbornik radova, Sedmi međunarodni naučni skup Dani porodičnog prava, Zaštita prava čovjeka kao pokretač razvoja porodičnog prava, Pravni fakultet Univerziteta "Džemal Bijedić" u Mostaru, Mostar, 2019., str. 9.-24. Za raspravu o transformaciji postupka radi razvoda braka u europskom kontekstu v. Aras Kramar, op. cit. u bilj. 9, str. 278.-279. i slj.

U francuskom Zakonu br. 1547 od 18. studenoga 2016. o modernizaciji pravosuđa u 21. stoljeću, op. cit. u bilj. 11, nadležnost notara propisana je među mjerama redefiniranja sudske nadležnosti u odnosu na svoju osnovnu funkciju.

21 Primjerice za razloge propisivanja nadležnosti notara za razvod braka u Grčkoj, v. tako Rozou, op. cit. u bilj. 12; Anthimos, A., Divorce in mutual consent before a notary public, 28. prosinca 2017., http://icl-in-greece.blogspot.com/2017-12-24-archive.html. Pristupljeno 23. lipnja 2020. Za Španjolsku v. Spanish Solutions, op. cit. u bilj. 13.

22 O građanskom parničnom postupku i njegovoj strukturi v. Triva, S.; Dika, M., Građansko parnično procesno pravo, VII. izd., Narodne novine, Zagreb, 2004., str. 2. i slj. 


\section{O SLOVENSKOJ REFORMI OBITELJSKIH POSTUPAKA}

Nakon što je četrdeset godina bio u primjeni slovenski Zakon o braku i obiteljskim odnosima (Zakon o zakonski zvezi in družinskih razmerjih ${ }^{23}$ ), 2017. godine Slovenija je donijela novi DZ. Uz određene iznimke, DZ se počeo primjenjivati 15. travnja 2019. (čl. 305. DZ-a). Njegovim donošenjem i stupanjem na snagu okončan je značajni i vremenski dugotrajni reformski proces. Nakon što je bilo ocijenjeno da ZZZDR (više) ne udovoljava suvremenim pravnim potrebama te da postoji potreba za obuhvatnim i sistemskim rješenjima, bilo se krenulo u reformu koja je bila okončana donošenjem Obiteljskog zakona 2011. godine. Međutim, taj Zakon nije bio stupio na snagu. On je bio predmet neuspješnog referenduma, i to zbog kontroverznih tema, propisivanja istospolnih zajednica, odnosno sklapanja toga životnog partnerstva. ${ }^{24}$

Ističe se da je novi DZ suvremen i moderan, prema djeci orijentiran zakon, koji je donio niz mjera u cilju zaštite prava i dobrobiti djeteta. ${ }^{25}$ Njime se interveniralo u sva važnija područja obiteljskog prava i postupka, među ostalim, brak, odnos roditelja i djece, podršku od strane države u slučaju teškoća u obiteljskom životu, mjere za zaštitu najboljeg interesa djeteta i obveze uzdržavanja, posvojenje, udomiteljstvo (rejništvo) te skrbništvo. Također, DZ-om su redefinirani i neki temeljni koncepti, poput roditeljskog prava (roditeljska pravica) koje je zamijenjeno konceptom roditeljske skrbi (starševska skrb). ${ }^{26} \mathrm{Na}$ području skrbništva i odraslih osoba, ističe se da DZ potiče i očuvanje autonomije te samostalnosti osoba s invaliditetom. ${ }^{27}$

U Sloveniji je donošenje DZ-a pratila i reforma izvanparničnog prava i postupka kojom je dopunjena ona obiteljska. U tom sklopu, donesen je i novi Zakon o izvanparničnom postupku (Zakon o nepravdnem postopku ${ }^{28}$ ). Obilježje je reforme obiteljskog i izvanparničnog prava i postupka u širenju nadležnosti suda u odnosu na nadležnost centra za socijalni rad na području posvojenja, ${ }^{29}$ udomiteljstva (rejništva) ${ }^{30}$ te skrbništva. ${ }^{31} \mathrm{Uz}$ to, u odnosu na prijašnje uređenje obiteljskih sudskih postupaka, došlo je do promjene u vrsti procedure. Prema novom ZNP-u,

23 Zakon o zakonski zvezi in družinskih razmerjih iz 1976., Uradni list RS, br. 69/2004 - službeni pročišćeni tekst, 101/2007 - Odluka USRS, 90/2011 - Odluka USRS, 84/2012 - Odluka USRS, 82/2015 - Odluka USRS, 15/2017 - Družinski zakonik (DZ), 30/2018 - Zakon o socialnem vključevanju invalidov (ZSVI), http://pisrs.si/Pis.web/pregledPredpisa?id=ZAKO40. Pristupljeno 24. lipnja 2020. (u daljnjem tekstu: ZZZDR).

O reformi slovenskog obiteljskog propisa v. više u: Novak, B., Novejši razvoj v slovenskem družinskem pravu, u: Europsko obiteljsko pravo, Narodne novine, Zagreb, 2013., str. 293.-296.

Vidjeti Kraljić, S., Ageizam i obiteljsko pravo - na primjeru sklapanja braka, posvojenja i skrbništva u Sloveniji, u: Zbornik radova, Sedmi međunarodni naučni skup Dani porodičnog prava, Zaštita prava čovjeka kao pokretač razvoja porodičnog prava, Pravni fakultet Univerziteta "Džemal Bijedić" u Mostaru, Mostar, 2019., str. 96.; Kraljić, S.; Drnovšek, K., Pomen in vloga pravnega standarda največje otrokove koristi v novem slovenskem Družinskem zakoniku in sodobni sodni praksi, u: Zbornik radova s V. međunarodnog savjetovanja Aktualnosti građanskog procesnog prava - nacionalna i usporedna pravnoteorijska i praktična dostignuća, Pravni fakultet Sveučilišta u Splitu, Split, 2019., str. 116.-119., 124.-126.

Vidjeti Drnovšek, K.; Markač Hrovatin, K., From Parental Rights to Parental Responsibility: Developments in Slovenian Family Law, u: Zbornik radova, Sedmi međunarodni naučni skup Dani porodičnog prava, Zaštita prava čovjeka kao pokretač razvoja porodičnog prava, Pravni fakultet Univerziteta "Džemal Bijedić” u Mostaru, Mostar, 2019., str. 106.-108. i slj. Vidjeti Kraljić, op. cit. u bilj. 25, str. 101.-103. Pristupljeno 24. lipnja 2020. (u daljnjem tekstu: ZNP). ZNP počeo se primjenjivati 15. travnja 2019. (čl. 224. ZNP-a). 
sve obiteljske stvari, uključujući bračne, maternitetske odnosno paternitetske sporove, one o roditeljskoj skrbi i uzdržavanju, rješavaju se prema pravilima izvanparničnog postupka. ${ }^{32}$ Time se slovensko obiteljsko i izvanparnično pravo i postupak približilo pravnim sustavima germanskog pravnog kruga. ${ }^{33}$

Uz opće odredbe (čl. 1. - čl. 42. ZNP-a), ZNP sadrži i odredbe o posebnim postupcima, među ostalim, za reguliranje osobnog stanja i obiteljskih odnosa (čl. 43. - čl. 122. ZNP-a). Među općim odredbama koje se primjenjuju u svim izvanparničnim postupcima, propisuju se temeljna načela (čl. 1. - čl. 9. ZNP-a), nadležnost i sastav suda (čl. 10. - čl. 20. ZNP-a), sudionici (čl. 21. - čl. 22. ZNP-a), prijedlog (čl. 23. - čl. 27. ZNP-a), ročište (čl. 28. - čl. 30. ZNP-a), odluke (čl. 31. ZNP-a), pravni lijekovi (čl. 32.-čl. 38. ZNP-a), sudske pristojbe i troškovi postupka (čl. 39. - čl. 41.) te odgovarajuća primjena zakona o parničnom postupku (ZPP; čl. 42. ZNP-a). Navedene opće odredbe ZNP-a primjenjuju se i na posebne postupke za reguliranje osobnog stanja i obiteljskih odnosa, ako odredbama toga poglavlja ZNP-a nije drugačije propisano.

Posebni postupci za reguliranje osobnog stanja i obiteljskih odnosa propisani su u desetom poglavlju ZNP-a primjenom dviju metoda. Prvo su istaknute opće odredbe koje se primjenjuju u svim takvim postupcima koji se odnose na obiteljske odnose (čl. 43. - čl. 56. ZNP-a), potom su istaknute posebne odredbe za postupak stavljanja odrasle osobe pod skrbništvo (čl. 57. čl. 70. ZNP-a), stjecanje potpune poslovne sposobnosti djeteta koji je postao roditelj (čl. 71. - čl. 75. ZNP-a), radi davanja dopuštenja za sklapanje braka (čl. 76.-čl. 79. ZNP-a), u bračnim sporovima (čl. 80. - čl. 87. ZNP-a), radi utvrđivanja i osporavanja očinstva i majčinstva (čl. 88. - čl. 92. ZNP-a), radi zaštite interesa djeteta (čl. 93. - čl. 122. ZNP-a), i to za odlučivanje o skrbi i odgoju djeteta, uzdržavanju i ostvarivanju osobnih odnosa s djetetom (čl. 102. - čl. 103. ZNP-a), o pitanjima ostvarivanja roditeljske skrbi koji značajno utječu na razvoj djeteta (čl. 104. ZNP-a), o mjerama za zaštitu interesa djeteta (čl. 105. - čl. 112. ZNP-a), o stavljanju djeteta pod skrbništvo (čl. 113. - čl. 115. ZNP-a), o smještaju djeteta u udomiteljstvo (rejništvo) (čl. 116. - čl. 118. ZNP-a), o povjeravanju roditeljske skrbi srodniku (čl. 119. - čl. 120. ZNP-a) te o zasnivanju i poništaju posvojenja djeteta (čl. 121. - čl. 122. ZNP-a).

Obilježje je posebnih izvanparničnih postupaka radi reguliranja osobnog stanja i obiteljskih odnosa u propisivanju isključenja javnosti (čl. 43. ZNP-a). Posebnosti se očituju i u zaštiti interesa djece i osoba koje se nisu u stanju skrbiti o svojim pravima i interesima zbog teškoća u

32 ZNP-om su izvršene intervencije u DZ te Zakon o parničnom postupku (Zakon o pravdnem postopku (ZPP), Uradni list RS, br. 73/2007 - službeni pročǐ̌ćeni tekst, 45/2008 - Zakon o arbitraži (ZArbit), 45/2008, 111/2008 - Odluka USRS, 57/2009 - Odluka USRS, 12/2010 - Odluka USRS, 50/2010 - Odluka USRS, 107/2010 - Odluka USRS, 75/2012 - Odluka USRS, 40/2013 - Odluka USRS, 92/2013 - Odluka USRS, 10/2014 - Odluka USRS, 48/2015 - Odluka USRS, 6/2017 - Odluka USRS, 10/2017, 16/2019 - Zakon o nepravdnem postopku (ZNP-1), 70/2019 - odluka USRS, http://pisrs.si/Pis.web/pregledPredpisa?id=ZAKO1212. Pristupljeno 24. lipnja 2020.; u daljnjem tekstu: ZPP). U ZPP-u brisane su odredbe koje su se odnosile na posebne parnične postupke u bračnim sporovima i sporovima iz odnosa između roditelja i djece (v. čl. 222. ZNP-a), dok je u DZ-u došlo do terminoloških promjena određivanjem novog pravozaštitnog puta, izvanparničnog postupka u obiteljskim stvarima (v. čl. 217. ZNP-a). O reformi slovenskog obiteljskog izvanparničnog prava i postupka v. više u: Rijavec, V.; Ivanc, T., Primerjalnopravni pregled nepravdnih postopkov v družinskih zadevah v razvojni perspektivi, Podjetje in delo, god. 44, br. 6/7, 2018., str. 1265.-1280.

U Austriji su pravila izvanparničnog postupka u obiteljskim stvarima sadržana u Saveznom zakonu o sudskom postupku u izvanparničnim pravnim stvarima (Bundesgesetz über das gerichtliche Verfahren in Rechtsangelegenheiten außer Streitsachen, Außerstreitgesetz) od 13. studenog 2003. (BGBl I 2003/111), s posljednjim izmjenama i dopunama (BGBl I 2019/38), https:// www.jusline.at/gesetz/aussstrg. Pristupljeno 24. lipnja 2020. U Njemačkoj su pravila izvanparničnog postupka u obiteljskim stvarima sadržana u Zakon o postupku u obiteljskim stvarima i stvarima dobrovoljne sudbenosti (Gesetz über das Verfahren in Familiensachen und in den Angelegenheiten der freiwilligen Gerichtsbarkeit) od 17. prosinca 2008. (BGBl I S 2586, 2587), s posljednjim izmjenama i dopunama (čl. 4. Zakona od 19. ožujka 2020., BGBl I S 541), https://www.gesetze-im-internet.de/ famfg/BJNR258700008.html. Pristupljeno 24. lipnja 2020. 
duševnom razvoju ili problema s duševnim zdravljem ili drugih okolnosti (čl. 6. st. 2. ZNP-a). U tom sklopu, propisana je i mogućnost da sud omogući odrasloj osobi pod skrbništvom i djetetu koje je navršilo petnaest godina da samostalno poduzimaju procesne radnje radi ostvarivanja svojih prava i interesa ako su u stanju razumjeti značenje i pravne posljedice tih radnji (čl. 45. st. 1. - 4. ZNP-a), kao i postavljanje kolizijskog skrbnika i traženje mišljenja centra za socijalni rad o osobi skrbnika u slučaju sukoba interesa djeteta i njegova zakonskoga zastupnika (čl. 45. st. 5. i 6 . ZNP-a).

U cilju načela žurnosti i zaštite interesa djece i odraslih osoba koje se nisu u stanju skrbiti o svojim pravima i interesima (čl. 6. ZNP-a), ZNP-om propisana je i obveza komunikacije u elektroničkom obliku između suda i centra za socijalni rad (čl. 47. ZNP-a). Uz to, uređena je obveza davanja osobnih podataka voditelja, organizacija i osoba koje raspolažu takvim podatcima na zahtjev suda radi zaštite djece i osoba koje se nisu u stanju skrbiti o svojim pravima i interesima zbog teškoća u duševnom razvoju ili problema s duševnim zdravljem ili drugih okolnosti, a protiv volje osobe na koju se ti podatci odnose (čl. 48. st. 1. ZNP-a). Tomu treba pridodati $\mathrm{i}$ istražno načelo kao određujuće u postupcima zaštite interesa djece i odraslih osoba koje se nisu u stanju skrbiti o svojim pravima i interesima (čl. 7. ZNP-a).

Prema čl. 48. st. 2. ZNP-a, sud može koristi, neovisno o ograničenjima propisanim ZPPom, kao dokaz i zvučne snimke ili audio-vizualne snimke razgovora s djetetom iz drugog sudskog postupka ili vještačenje u pisanu obliku sastavljeno u drugom sudskom postupku ako ocijeni da se samo na taj način mogu pravovremeno zaštititi interesi djece i osoba koje se nisu u stanju skrbiti o svojim pravima i interesima zbog teškoća u duševnom razvoju ili problema s duševnim zdravljem ili drugih okolnosti (čl. 48. st. 2. ZNP-a).

U sklopu istražnog načela, treba istaknuti i pravilo prema kojem, ako je sudionik predložio izvođenje dokaza a ne predujmi iznos koji je potreban za njegovo izvođenje i ako sud ocijeni da se taj dokaz treba izvesti, troškovi izvođenja takvog dokaza predujmljuju se iz sredstava suda. Također, to pravilo vrijedi i za dokaze koje je sud odlučio izvesti po službenoj dužnosti (čl. 55. st. 1. ZNP-a). Pritom o troškovima postupka u ovim postupcima reguliranja osobnog stanja i obiteljskih odnosa sud odlučuje po slobodnoj ocjeni (čl. 55. st. 2. ZNP-a).

Posebnosti se očituju i u žurnosti postupka (čl. 6. ZNP-a), kao i u posebnim pravilima o zakazivanju ročišta u ovim postupcima koja se moraju zakazati na način da sudionicima ostane dovoljno vremena za pripremu, a najmanje petnaest dana, osim ako zaštita interesa djece i osoba koje se nisu u stanju skrbiti o svojim pravima i interesima zbog teškoća u duševnom razvoju ili problema s duševnim zdravljem ili drugih okolnosti ne opravdava kraći rok, koji ne bi smio biti kraći od osam dana (čl. 50. st. 1. ZNP-a). Rok za odgovor na prijedlog kojim se pokreće postupak je trideset dana, osim ako zaštita interesa djece i osoba koje se nisu u stanju skrbiti o svojim pravima i interesima ne opravdava kraći rok, koji ne bi smio biti kraći od petnaest dana (čl. 50. st. 2. ZNP-a).

U odnosu na načelo dispozicije i stranačku autonomiju, treba istaknuti da je ZNP-om sudska nagodba dopuštena u postupcima odlučivanja o skrbi i odgoju djeteta, o uzdržavanju i ostvarivanju osobnih odnosa s djetetom, kao i u postupcima odlučivanja o pitanjima ostvarivanja roditeljske skrbi koji značajno utječu na djetetov razvoj ako je ona u skladu s interesom djeteta (čl. 51. ZNP-a). S druge strane, u drugim posebnim postupcima za reguliranje osobnog stanja i obiteljskih odnosa, odredbe o sudskoj nagodbi se ne primjenjuju (čl. 51. st. 1. ZNP-a). 
Paralelno sa širenjem izvanparnične jurisdikcije sudova, slovensku reformu obiteljskog i izvanparničnog prava i postupka obilježilo je i širenje kompetencija javnih bilježnika. Prema DZ-u, bračni drugovi mogu sporazumno urediti svoje imovinske odnose, uključujući i sporazum o međusobnom uzdržavanju, odnosno o uzdržavanju za slučaj razvoda braka te je tu značajna uloga javnih bilježnika (čl. 85. - čl. 88., čl. 101. DZ-a). ${ }^{34}$ Uz to, ustrojen je Registar ugovora o uređenju imovinskopravnih odnosa (izvan)bračnih drugova, kao elektronički vođena zbirka podataka, koji vodi Notarska zbornica Slovenije (čl. 90. - čl. 94. DZ-a). ${ }^{35}$ Značajno je istaknuti i kompetencije javnih bilježnika i na području uzdržavanja punoljetnog djeteta te roditelja. O uzdržavanju punoljetnog djeteta, kao i roditelja koje mora plaćati punoljetno dijete, vjerovnik i obveznik uzdržavanja mogu zaključiti sporazum u obliku ovršnog javnobilježničkog akta (čl. 192. - čl. 193. DZ-a). ${ }^{36}$

Među značajnijim obilježjima slovenske reforme, u odnosu na kompetencije javnih bilježnika na području osobnog stanja i obiteljskih odnosa, očituje se propisivanje njihove nadležnosti za sporazumni razvod braka (v. infra ad 3.).

\section{RAZVOD BRAKA PRED SLOVENSKIM JAVNIM BILJEŽNICIMA}

Nakon reforme obiteljskog i izvanparničnog prava i postupka, na području razvoda braka, prisutne su tri vrste postupaka. Prema DZ-u i ZNP-u, na području sporazumnog razvoda braka propisana je nadležnost suda i javnog bilježnika. Sud će razvesti brak na temelju sporazuma bračnih drugova ako su se oni sporazumjeli o skrbi, odgoju i uzdržavanju zajedničke djece i o njihovim osobnim odnosima s roditeljima te ako su priložili, u obliku ovršnog javnobilježničkog akta, sklopljen sporazum o diobi zajedničke imovine, o tome tko od njih ostaje ili postaje najmoprimac stana, o uzdržavanju bračnog druga koji nema sredstva za življenje i bez svoje krivnje nije zaposlen (čl. 96. DZ-a, čl. 80. - čl. 87. ZNP-a). Međutim, u slučaju bračnih drugova koji nemaju zajedničku djecu nad kojom ostvaruju roditeljsku skrb, a žele se sporazumno razvesti, propisana je nadležnost javnih bilježnika za sporazumni razvod takvog braka (čl. 97. DZ-a). Ako izostane sporazum bračnih drugova u odnosu na razvod braka i/ili njegove pravne posljedice, propisana je nadležnost suda u izvanparničnom postupku (čl. 98. DZ-a, čl. 80.-čl. 87. ZNP-a).

Novina reformiranog postupka radi razvoda braka je u propisivanju prethodnog savjetovanja kao procesne pretpostavke postupka radi razvoda braka bračnih drugova koji imaju zajedničku djecu nad kojom ostvaruju roditeljsku skrb (čl. 200. DZ-a; čl. 82. st. 2., čl. 83. ZNP-a). ${ }^{37}$

34 Za sastavljanje javnobilježničke isprave, odnosno akta v. čl. 20.-čl. 59. Zakona o notariatu (ZN), Uradni list RS, br. 2/2007 službeni pročišćeni tekst, 33/2007 - Zakon o spremembah in dopolnitvah Zakona o sodnem registru (ZSReg-B), 45/2008, 91/2013, http://pisrs.si/Pis.web/pregledPredpisa?id=ZAKO1329. Pristupljeno 25. lipnja 2020. O obvezama javnih bilježnika prilikom sastavljanja javnobilježničkog akta v. i Gornjec, A., Pogodba o ureditvi premoženjskopravnih razmerij, magistarski rad, Pravni fakultet Sveučilišta u Ljubljani, Ljubljana, 2018., str. 22.-24. O tome v. više u: Kraljić, S., Družinski zakonik s komentarjem, Poslovna založba MB, založništvo d.o.o., Maribor, 2018., str. 257.267.

36 Ibid., str. 628.

37 O prethodnom savjetovanju, stručnom savjetovanju para te medijaciji u reformiranom slovenskom pravu v. više u: ibid., str. 643.-709.; Kraljić, Drnovšek, op. cit. u bilj. 25, str. 125.-126. 
U takvim slučajevima, razvod braka je dopušten (samo) u sudskom izvanparničnom postupku pokrenutom na prijedlog obaju bračnih drugova, ako postoji sporazum o pitanjima koja se tiču roditeljske skrbi i imovinskih odnosa bračnih drugova (čl. 96. DZ-a u vezi s čl. 81. st. 4. ZNP-a), ili na prijedlog jednog od bračnih drugova, u slučaju izostanka takvog sporazuma (čl. 98. DZ-a u vezi s čl. 81. st. 3. ZNP-a).

Uz okolnost da bračni drugovi nemaju zajedničku djecu nad kojom ostvaruju roditeljsku skrb, pozitivna pretpostavka sporazumnog razvoda braka pred javnim bilježnikom je sporazum bračnih drugova o diobi zajedničke imovine, o tome tko od njih ostaje ili postaje najmoprimac stana, o uzdržavanju bračnog druga koji nema sredstava za život i bez svoje krivnje nije zaposlen (čl. 97. st. 1. DZ-a). Brak se razvodi sporazumom bračnih drugova o razvodu braka i navedenim pitanjima njihova imovinskopravnog odnosa u obliku javnobilježničkog akta (čl. 97. st. 1. DZ-a). Pritom je brak razveden danom potpisivanja javnobilježničkog akta te je on osnova za upis razvoda braka u matični registar (čl. 97. st. 2. DZ-a). U tu svrhu, javni bilježnik je dužan osam dana od potpisivanja javnobilježničkog akta dostaviti ga nadležnom upravnom tijelu za registar osobnih stanja (čl. 97. st. 3. DZ-a).

U literaturi se među razlozima propisivanja nadležnosti javnih bilježnika za ovaj oblik sporazumnog razvoda braka ističe potreba modernizacije postupka razvoda braka i prilagođavanje suvremenim trendovima na ovom području, posebice dinamika života, zbog koje je potrebno onim bračnim drugovima koji nemaju zajedničku djecu, a time i potrebu uređivanja ostvarivanja roditeljske skrbi te obvezu prethodnog savjetovanja, omogućiti da se brže razvedu u pojednostavnjenom postupku. ${ }^{38}$ Tomu treba pridodati i sustavnost uređenja. Odredbe o razvodu braka pred javnim bilježnikom primjenjuju se i na prestanak životnog partnerstva (čl. 4. st. 10. Zakona o partnerski zvezi ${ }^{39}$ ).

Uz navedene odredbe čl. 97. DZ-a, taj Zakon ni ZN ne sadrže posebne odredbe o postupanju javnog bilježnika u slučaju sporazumnog razvoda braka. Stoga bi na taj postupak i javnobilježnički akt o sporazumnom razvodu braka, trebalo vrijediti ono što je ZN-om propisao inače za sastavljanje javnobilježničkih isprava, odnosno akata (čl. 20. - čl. 59. ZN-a). Tijekom sporazumnog razvoda braka ističe se dužnost javnog bilježnika da bračne drugove informira na razumljiv način o mogućnosti i posljedicama razvoda braka. U tom smislu, javni bilježnik treba upoznati bračne drugove sa sadržajem i pravnim posljedicama namjeravanog sporazumnog razvoda braka te ih upozoriti na uobičajene rizike povezane sa zaključenjem takvog pravnog posla ili izjave volje (čl. 42. reč. 1. ZN-a) ${ }^{40} \mathrm{Uz}$ to, javni bilježnik treba upozoriti bračne drugove i na druge okolnosti u odnosu na namjeravani razvod braka ako su mu one poznate (čl. 42. reč. 2. ZN-a). Posebice treba odvratiti bračne drugove od davanja nejasnih, nerazumljivih ili dvosmislenih izjava te ih upozoriti na moguće pravne posljedice takvih izjava (čl. 42. reč. 3. ZN-a). Međutim, ako bračni drugovi inzistiraju da se takve izjave unesu u javnobilježničku ispravu,

38 Kraljić, S., Sporazumna razveza pred notarjem v luči novega slovenskega Družinskega zakonika, u: Zbornik radova s IV. međunarodnog savjetovanja Aktualnosti građanskog procesnog prava - nacionalna i usporedna pravnoteorijska i praktična dostignuća, Pravni fakultet Sveučilišta u Splitu, Split, 2018., str. 185., 187., 191. 
javni bilježnik ih mora unijeti, kao i upozorenje koje je dano u odnosu na njih i njihove pravne posljedice (čl. 42. reč. 4. ZN-a).

Javni bilježnik mora biti nepristran u odnosu na obje stranke i postupati prema njima jednako. U literaturi se ističe da javni bilježnik mora odstupiti od toga načela ako utvrdi da je jedan od bračnih drugova u slabijoj poziciji u odnosu na drugog, kako bi se osigurala njihova ravnopravnost. ${ }^{41}$

Iako DZ izrijekom ne propisuje da bračni drugovi moraju zajedno i osobno biti prisutni kod javnog bilježnika pri sporazumnom razvodu braka, ističe se da je sporazumni razvod braka u obliku javnobilježničkog akta dopušten samo ako su osobno i zajedno prisutna oba bračna druga, bez punomoćnika. ${ }^{42}$ Također, javni bilježnik mora odbiti sastavljanje javnobilježničkog akta koji sadrži sporazum o razvodu braka u slučaju da utvrdi mane volje bračnih drugova, odnosno da nije riječ o slobodnoj volji jednog od bračnih drugova. ${ }^{43} \mathrm{Na}$ isti način javni bilježnik trebao bi postupiti i ako utvrdi da je jedan od bračnih drugova podnio prijedlog za pokretanje izvanparničnog postupka radi razvoda braka pred sudom. ${ }^{44}$

Ako javni bilježnik utvrdi da nisu ispunjene pretpostavke sporazumnog razvoda braka, a time i sastavljanja javnobilježničkog akta koji sadrži sporazum o razvodu braka i pitanjima imovinskopravnog odnosa bračnih drugova, mora odbiti sastavljanje toga akta (arg. ex čl. 97. DZ-a). U tom slučaju, bračni drugovi imaju mogućnost pokretanja izvanparničnog postupka radi razvoda braka, ovisno o pretpostavkama, prijedlogom obaju bračnih drugova za sporazumni razvod braka (čl. 81. st. 4. ZNP-a) ili prijedlogom jednog od bračnih drugova (čl. 81. st. 3. ZNP-a).

Na sastavljanje javnobilježničkog akta o sporazumnom razvodu braka u fizičkom obliku primjenjuju se odredbe ZN-a koje općenito vrijede za sastavljanje takvih akata (v. posebice čl. 36., čl. 37. ZN-a). Uzimajući u obzir tendencije modernizacije i elektronifikacije postupanja nadležnih tijela, treba istaknuti i mogućnost sastavljanja javnobilježničkog akta o sporazumnom razvodu braka u elektroničkom obliku. Prema čl. 38.a st. 1. ZN-a, javnobilježnički akt u elektroničkom obliku potpisuju elektroničkim putem bračni drugovi sigurnim elektroničkim potpisom, ovjerenim kvalificiranim certifikatom. Tako potpisan javnobilježnički akt o sporazumnom razvodu braka potpisuje i javni bilježnik sigurnim elektroničkim potpisom, ovjerenim kvalificiranim certifikatom. Javni bilježnik dodaje javnobilježničkom aktu i vremenski žig. $\mathrm{Na}$ taj način potpisan javnobilježnički akt o sporazumnom razvodu braka jednakovrijedan je javnobilježničkom aktu o sporazumnom razvodu braka u fizičkom obliku, s vlastoručnim potpisom i žigom ili javnobilježničkim pečatom (čl. 38.a st. 1. ZN-a). ${ }^{45}$

41 Kraljić, op. cit. u bilj. 35, str. 284.; Rijavec, op. cit. u bilj. 40, str. 56.

42 Tako Kraljić, op. cit. u bilj. 35, str. 284.; Tavčar Pasar, M., Družinski zakonik: razveza zakonske zveze tudi pred notarjem, Notarski vestnik, br. 10, 2019., str. 61.-62. 


\section{ANALIZA JAVNOBILJEŽNIČKOG RAZVODA BRAKA IZ HRVATSKE PERSPEKTIVE}

Poredbenopravno istraživanje ukazuje na okolnost da se propisivanje sporazumnog razvoda braka pred javnim bilježnicima javilo među temama modernizacije i rasterećenja pravosuđa. ${ }^{46}$ U prilog propisivanja kompetencija javnih bilježnika i na ovom području istaknuto je i pojednostavnjenje, fleksibilnost i ubrzanje postupka za stranke. ${ }^{47}$ Promatrajući hrvatski pravni sustav, treba primijetiti da je posljednjom reformom obiteljskog prava i postupka pojednostavnjenje i ubrzanje učinjeno na području sporazumnog razvoda braka, posebice razvoda braka bračnih drugova koji nemaju zajedničku djecu nad kojom ostvaruju roditeljsku skrb, propisivanjem izvanparničnog postupka kao pravnozaštitnog puta (čl. 50. st. 1., čl. 453. - čl. 460. Obiteljskog zakona $^{48}$ ). Tomu treba pridodati i da se novi institut obveznog savjetovanja, kao procesna pretpostavka, javlja za one sudske postupke radi razvoda braka u kojem postoje zajednička djeca nad kojom se ostvaruje roditeljska skrb (čl. 322. st. 1. t. 1., čl. 379. st. 1., čl. 456. ObZ-a 15).

Prema hrvatskom uređenju, u izvanparničnom postupku radi sporazumnog razvoda braka bračnih drugova bez zajedničke djece nad kojom ostvaruju roditeljsku skrb, sud donosi rješenje na temelju sporazuma bračnih drugova o tome da se žele razvesti. Pretpostavka tog oblika sporazumnog razvoda braka nije i sporazumna dioba bračne stečevine te uređenje drugih pitanja njihova imovinskopravnog odnosa (arg. ex: čl. 45., čl. 52. ObZ-a 15). Uloga suca, dakle, iscrpljuje se u aktu državne vlasti kojim se ta pravna zajednica, brak, razvodi na temelju sporazumnog traženja obaju bračnih drugova.

Diobu bračne stečevine, uzdržavanje i svoje imovinske odnose zbog razvoda braka bračni drugovi mogu sporazumno urediti pred javnim bilježnikom (arg ex: čl. 45., čl. 302. ObZ-a 15). Tomu treba pridodati i ulogu i kompetencije javnih bilježnika u sklopu zahtjeva za odgovarajuće upise prijenosa prava nad nekretninama na temelju sporazuma bračnih drugova. Odredbama čl. 105. st. 1. Zakona o zemljišnim knjigama, propisana je mogućnost podnošenja zemljišnoknjižnog prijedloga za upis elektronički, među ostalim, i preko javnog bilježnika. ${ }^{49}$

Uzimajući u obzir okolnost da je posljednja hrvatska reforma obiteljskog prava i postupka pojednostavnila sporazumni razvod braka bračnih drugova bez zajedničke djece nad kojom ostvaruju roditeljsku skrb, kao i kompetencije javnih bilježnika u pogledu sporazumnog uređenja imovinskih odnosa bračnih drugova, mogućnost podnošenja zemljišnoknjižnih prijedloga za upis elektroničkim putem, otvara se pitanje propisivanja kompetencija javnih bilježnika i za sporazumni razvod braka u obliku javnobilježničkog akta. Uz razloge postupnosti, rasterećenja, modernizacije, posebice elektronifikacije pravosuđa, u prilog propisivanja takvog oblika sporazumnog razvoda braka govorilo bi i načelo "sve na jednom mjestu”. Bračni bi se drugovi, osim razvoda braka, mogli kod javnog bilježnika sporazumjeti i o pojedinim pitanjima njihova imovinskopravnog odnosa, uzdržavanju, diobi bračne stečevine te bi mogli tražiti da javni bi-

46 Vidjeti supra ad bilj. 19.-21.

47 Primjerice v. Kraljić, op. cit. u bilj. 38, str. 187., 191.; Rozou, op. cit. u bilj. 12; Spanish Solutions, op. cit. u bilj. 13.

48 Obiteljski zakon iz 2015., Narodne novine RH, br. 103/2015, 98/2019, 47/2020 - v. čl. 35. Zakona o Centru za posebno skrbništvo (u daljnjem tekstu: ObZ 15).

49 Zakon o zemljišnim knjigama, Narodne novine RH, br. 63/2019; v. posebice čl. 11. - čl. 14. Pravilnika o elektroničkom poslovanju korisnika i ovlaštenih korisnika sustava zemljišnih knjiga, Narodne novine RH, br. 108/2019. 
lježnik podnese odgovarajuće zemljišnoknjižne prijedloge za upis elektroničkim putem. Time bi se značajno pojednostavnili i ubrzali ti postupci, a pozitivni učinci bi se mogli očekivati i u odnosu na pitanje troškova takvih postupaka. ${ }^{50}$

Promatrajući pitanje troškova sporazumnog razvoda braka pred javnim bilježnicima, u pojedinim zemljama ističu se veći troškovi postupka sporazumnog razvoda braka pred javnim bilježnicima, u odnosu na sudski. ${ }^{51}$ Treba istaknuti, međutim, da je jedno od obilježja sporazumnog razvoda braka pred javnim bilježnicima u pojedinim od tih država (Španjolska, Francuska, Grčka) u obvezi odvjetničkog zastupanja bračnih drugova. ${ }^{52} \mathrm{Uz}$ to, u nekim od tih pravnih sustava, bračni drugovi se moraju sporazumjeti o diobi zajedničke imovine, pitanjima međusobnog uzdržavanja, i drugim imovinskopravnim pitanjima (Španjolska, ${ }^{53}$ Francuska ${ }^{54}$ ), a u nekima od njih i o pitanjima roditeljske skrbi, njezina ostvarivanja, uzdržavanja zajedničkog djeteta nad kojim ostvaruju roditeljsku skrb (Francuska, ${ }^{55}$ Grčka $^{56}$ ). Stoga se u tim pravnim sustavima, uz trošak javnobilježničke nagrade i naknade, javlja i odvjetnički trošak koji, među ostalim, ovisi i o vrijednosti predmeta spora (imovine bračnih drugova). S druge strane, kao što je u poredbenopravnoj analizi slovenskog modela istaknuto, u tom pravnom sustavu ne postoji obveza odvjetničkog zastupanja bračnih drugova pri sporazumnom razvodu braka. Tomu treba pridodati da se hrvatski pravni sustav temelji na načelu da sporazum bračnih drugova o diobi bračne stečevine i drugim imovinskopravnim pitanjima nije pretpostavka sporazumnog razvoda braka. Stoga bi trebalo i te okolnosti uzeti u obzir tijekom rasprave i analize troškova javnobilježničkog oblika sporazumnog razvoda braka u hrvatskoj perspektivi.

Poredbenopravno istraživanje ukazuje na postojanje različitih pristupa sporazumnom razvodu braka i kompetencijama javnih bilježnika u slučajevima kada oni imaju zajedničku djecu nad kojom ostvaruju roditeljsku skrb. Neki pravni sustavi otvaraju mogućnost sporazumnog razvoda braka pred javnim bilježnikom i kad je riječ o takvom slučaju te inzistiraju na sporazumu o pitanjima roditeljske skrbi i uzdržavanja djeteta (Latvija, Rumunjska, Francuska, Grčka). ${ }^{57}$ Pritom u nekima od njih propisana je i ovlast javnog bilježnika da zatraži odgovarajuća izvješća od skrbničkih tijela u odnosu na sporazum roditelja i dobrobit djeteta (Rumunjska). ${ }^{58}$ U ostalim sustavima koji poznaju ovaj oblik razvoda braka isključena je mogućnost sporazumnog razvoda braka pred javnim bilježnikom ako dijete želi ostvarivati svoje pravo na izraža-

50 U praksi se bilježe pozitivni rezultati u odnosu na mogućnost podnošenja odgovarajućih zemljišnoknjižnih prijedloge za upis elektroničkim putem. Također, treba istaknuti i niži trošak sudske pristojbe uslijed okolnosti da se prijedlog podnosi elektroničkim putem. V. Višestruko povećan broj elektroničkih prijedloga za upis u zemljišne knjige, IUS-INFO, 4. ožujka 2020., http://www.iusinfo.hr/DailyContent/News.aspx?id=40813\#. Pristupljeno 26. lipnja 2020.

Primjerice za Grčku, v. Rozou, op. cit. u bilj. 12; za Španjolsku v. Grant, E., Spanish notaries given power to grant divorce, 6. srpnja 2015., http://www.spanishbarrister.com/spanish-notaries-given-power-to-grant-divorce/. Pristupljeno 26. lipnja 2020. Za Španjolsku v. Spanish Solutions, op. cit. u bilj. 13; za Francusku, v. Notaries of France, op. cit. u bilj. 14; za Grčku, v. Rozou, op. cit. u bilj. 12. 
vanje mišljenja pred sudom (Francuska) ${ }^{59}$ ili uopće, ako postoje zajednička djeca nad kojom se ostvaruje roditeljska skrb (Španjolska, Slovenija). ${ }^{60}$

Promatrajući hrvatski pravni sustav, posebice okolnost da je posljednjom reformom obiteljskog prava i postupka pojednostavnjenje i ubrzanje postupka učinjeno na području sporazumnog razvoda braka bračnih drugova koji nemaju zajedničku djecu nad kojom ostvaruju roditeljsku skrb, a time ni obvezu obveznog savjetovanja, razlozi postupnosti govorili bi u prilog propisivanja kompetencija javih bilježnika za sporazumni razvod takvih brakova u obliku javnobilježničkog akta. U ovom slučaju javni bilježnik nema sudsku funkciju, ne "odlučuje", već sastavlja javnobilježnički akt ako su ispunjene pretpostavke takva oblika sporazumnog razvoda braka (sporazumna, slobodna volja bračnih drugova, izostanak zajedničke djece nad kojom se ostvaruje roditeljska skrb).

Na europskoj razini, treba istaknuti i donošenje nove Uredbe Vijeća (EU) 2019/1111 od 25. lipnja 2019. o nadležnosti, priznavanju i ovrsi odluka u bračnim predmetima i predmetima roditeljske odgovornosti, te o međunarodnoj otmici djece (preinaka) ${ }^{61} \mathrm{BU}$ II ter prepoznaje izrijekom i ovakve oblike sporazumnog razvoda braka te kompetencije javnih bilježnika. ${ }^{62}$ Time su jasno postavljeni temelji i mogućnost priznavanja, odnosno prihvaćanja i pravnog prometa javnobilježničkih akata o sporazumnom razvodu braka, i u onim državama članicama EU-a koje (još) ne poznaju takve kompetencije javnih bilježnika latinskoga tipa (v. t. 70. Preambule BU II ter) ${ }^{63}$

\section{ZAKLJUČNE NAPOMENE}

Sporazumni razvod braka bračnih drugova, posebice onih bez zajedničke djece nad kojom ostvaruju roditeljsku skrb, zauzet će neizbježno svoje mjesto, pro futuro, u budućim reformskim nastojanjima, kako u Hrvatskoj tako i u ostalim susjednim državama koje teže modernizaciji pravosuđa, njegovu rasterećenju, redefiniranju osnovnih funkcija suda, elektronifikaciji pravnog prometa.

Prigovori da propisivanje mogućnosti sporazumnog razvoda braka pred javnim bilježnicima dovodi do brzopletih i nepromišljenih odluka o razvodu brakova, kao i da poimanje braka kao institucije zahtijeva konvencionalni pristup, sudski postupak radi razvoda braka, čini se, već su stvar prošlosti. To potvrđuje pojednostavnjenje postupka radi sporazumnog razvoda braka bračnih drugova, posebice onih bez zajedničke djece, kojem svjedočimo u hrvatskim i europskim okvirima. Konačno, nije svaki tip razvoda braka isti, niti je svaki oblik postupka radi razvoda braka prikladan za sve bračne drugove.

Pro futuro, pri promišljanju sporazumnog razvoda braka pred javnim bilježnikom trebalo bi uzeti u obzir argument postupnosti te propisati tu mogućnost u odnosu na one bračne drugove

59 Vidjeti supra ad bilj. 14.

60 Vidjeti supra ad bilj. 13. te dio 3.

61 Uredba Vijeća (EU) 2019/1111 od 25. lipnja 2019. o nadležnosti, priznavanju i ovrsi odluka u bračnim predmetima i predmetima roditeljske odgovornosti, te o međunarodnoj otmici djece (preinaka), Službeni list EU-a, br. L 178/2019, str. 1.-115. (u daljnjem tekstu: BU II ter). Uz određene iznimke, BU II ter se počinje primjenjivati 1. kolovoza 2022. (čl. 105. BU II ter).

Vidjeti t. 14. Preambule BU-a II ter. 
koji nemaju zajedničku djecu nad kojom ostvaruju roditeljsku skrb. Pritom bi svakako trebalo voditi računa ne samo o pojednostavnjenju i ubrzanju takvih postupaka radi sporazumnog razvoda braka, već i o troškovnoj komponenti. Prema hrvatskom uređenju, sudski postupak u građanskim stvarima, različito od nekih poredbenopravnih sustava uključenih u analizu, ne temelji se, u načelu, na obvezi odvjetničkog zastupanja. Stoga bi tu okolnost trebalo, također, uzeti u obzir kod projekcija de lege ferenda. Tomu treba pridodati da u hrvatskom sustavu pretpostavka (sporazumnog) razvoda braka bračnih drugova nije dioba bračne stečevine i sporazum o drugim imovinskopravnim pitanjima. Na tome bi se trebale temeljiti i projekcije de lege ferenda. Sporazumijevanje o diobi bračne stečevine, uzdržavanju te drugim imovinskopravnim pitanjima, kao i odgovarajući zemljišnoknjižni prijedlozi za upis elektroničkim putem, trebali bi biti mogućnost koju bi bračni drugovi, prema svojem izboru, ostvarivali kod javnog bilježnika uz sporazumni razvod braka, prema načelu "sve na jednom mjestu".

Argumenti cjelovitosti i koherentnosti uređenja govorili bi i u prilog propisivanja kompetencija javnih bilježnika i za raskid životnog partnerstva, analogno rješenjima koja bi vrijedila za sporazumni razvod braka bračnih drugova. ${ }^{64}$

\section{LITERATURA}

1. Antokolskaia, M., Divorce law in a European perspective, u: Scherpe, J. M. (ur.), European Family Law, Volume III, Family Law in a European Perspective, Edward Elgar Publishing, Cheltenham/Northampton, 2016., str. 41.-81.

2. Aras Kramar, Slađana, The transformation of divorce procedure in Europe, Familia, Il diritto della famiglia e delle successioni in Europa, br. 3, 2018., str. 277.-298.

3. Crăciun, N., The Divorce by the Public Notary. Proceedings, Bulletin of the Transilvania University of Braşov, Series VII: Social Sciences, Law, vol 7(56), br. 2, 2014., str. 189.-196.

4. Dika, M., Osvrt na povijesni razvoj europskoga latinskoga javnog bilježništva, u: Crnić, I.; Dika, M., Zakon o javnom bilježništvu, Organizator, Zagreb, 1994., str. 29.-40.

5. Drnovšek, K.; Markač Hrovatin, K., From Parental Rights to Parental Responsibility: Developments in Slovenian Family Law, u: Zbornik radova, Sedmi međunarodni naučni skup Dani porodičnog prava, Zaštita prava čovjeka kao pokretač razvoja porodičnog prava, Pravni fakultet Univerziteta "Džemal Bijedić" u Mostaru, Mostar, 2019., str. 105.-122.

6. Freeman, M., Family Values and Family Justice, u: Family Values and Family Justice, Ashgate, Farnham/Burlington, 2010., str. 1.-45.

7. Frîntu, V-M.; Gherghe, E-R., Divorce through the Spouses' Agreement by Administrative Method or Notarial Procedure, Advances in Fiscal, Political and Law Science, 2013., str. 185.-190., http://www. wseas.us/e-library/conferences/2013/Brasov/EPLS/EPLS-30.pdf. Pristupljeno 19. lipnja 2020.

8. Gornjec, A., Pogodba o ureditvi premoženjskopravnih razmerij, magistarski rad, Pravni fakultet Sveučilišta u Ljubljani, Ljubljana, 2018.

9. Kraljić, S., Ageizam i obiteljsko pravo - na primjeru sklapanja braka, posvojenja i skrbništva u Sloveniji, u: Zbornik radova, Sedmi međunarodni naučni skup Dani porodičnog prava, Zaštita prava čovjeka

64 Treba istaknuti da je čl. 29. st. 3. Zakona o životnom partnerstvu (Narodne novine RH, broj 92/2014, 98/2019) (već) propisana mogućnost (administrativnog) raskida životnog partnerstva na temelju sporazumne izjave dane kod matičara ako u životnoj zajednici ne živi maloljetno dijete. 
kao pokretač razvoja porodičnog prava, Pravni fakultet Univerziteta "Džemal Bijedić" u Mostaru, Mostar, 2019., str. 93.-104.

10. Kraljić, S.; Drnovšek, K., Pomen in vloga pravnega standarda največje otrokove koristi v novem slovenskem Družinskem zakoniku in sodobni sodni praksi, u: Zbornik radova s V. međunarodnog savjetovanja Aktualnosti građanskog procesnog prava - nacionalna i usporedna pravnoteorijska i praktična dostignuća, Pravni fakultet Sveučilišta u Splitu, Split, 2019., str. 113.-129.

11. Kraljić, S., Družinski zakonik s komentarjem, Poslovna založba MB, založništvo d.o.o., Maribor, 2018.

12. Kraljić, S., Sporazumna razveza pred notarjem v luči novega slovenskega Družinskega zakonika, u: Zbornik radova s IV. međunarodnog savjetovanja Aktualnosti građanskog procesnog prava - nacionalna i usporedna pravnoteorijska i praktična dostignuća, Pravni fakultet Sveučilišta u Splitu, Split, 2018., str. 185.-192.

13. Novak, B., Novejši razvoj v slovenskem družinskem pravu, u: Europsko obiteljsko pravo, Narodne novine, Zagreb, 2013., str. 293.-310.

14. Papa, A. D.; Tăpuş, I. F., Notary Procedure and Judicial Procedure for the Divorce with Spouses' Agreement, Challenges of the Knowledge Society. Private Law, 2013., str. 344.-354., http://cks.univnt. ro/uploads/cks-2013-articles/index.php?dir=1-Juridical-Sciences\%2 F\&download=cks-2013_lawart-041.pdf. Pristupljeno 19. lipnja 2020.

15. Podgoršek, B., Pogodba o ureditvi premoženjskopravnih razmerij med zakoncema, Notarski vestnik, br. 10, 2017., str. 21.-32.

16. Ponjavić, Z., Porodično pravo od institucije do ugovora, u: Zbornik radova, Sedmi međunarodni naučni skup Dani porodičnog prava, Zaštita prava čovjeka kao pokretač razvoja porodičnog prava, Pravni fakultet Univerziteta "Džemal Bijedić” u Mostaru, Mostar, 2019., str. 9.-25.

17. Rijavec, V.; Ivanc, T., Primerjalnopravni pregled nepravdnih postopkov $v$ družinskih zadevah $v$ razvojni perspektivi, Podjetje in delo, god. 44, br. 6/7, 2018., str. 1265.-1280.

18. Rijavec, V., Notariat quo vadis?, Notarski vestnik, br. 10, 2017., str. 55.-60.

19. Tavčar Pasar, M., Družinski zakonik: razveza zakonske zveze tudi pred notarjem, Notarski vestnik, br. 10, 2019., str. 61.-63.

20. Triva, S.; Dika, M., Građansko parnično procesno pravo, VII. izdanje, Narodne novine, Zagreb, 2004.

21. Woschnak, K., Javnobilježnička reforma u Srednjoj Europi od 1989. do 1995. iz austrijske perspektive, Javni bilježnik, br. 39, 2013., str. 9.-16.

22. Zimmermann, S.; Schmitz-Vornmoor, A., Javnobilježnička služba u Europskoj uniji. Filozofija struke i trendovi razvoja, harmonizacija i ujednačavanje, Zbornik Pravnog fakulteta u Zagrebu, vol. 59, br. 6, 2009., str. 1217.-1250.

\section{POPIS PROPISA, AKATA I SUDSKIH ODLUKA}

1. Družinskizakonik(DZ), Uradni list RS, br. 15/2017, 21/2018 - Zakon o nevladnih organizacijah (ZNOrg), 22/2019, 67/2019 - Zakon o spremembah in dopolnitvah Zakona o matičnem registru (ZMatR-C), http:// www.pisrs.si/Pis.web/pregledPredpisa?id=ZAKO7556. Pristupljeno 23. lipnja 2020.

2. Građanski zakonik Francuske, u verziji od 14. veljače 2020., https://www.legifrance.gouv.fr/affichCode.do?cidTexte=LEGITEXT000006070721. Pristupljeno 19. lipnja 2020.

3. Građanski zakonik Latvije (Valdības Vēstnesis, 41, 20. veljače 1937.), s posljednjim izmjenama i dopunama od 5. prosinca 2019. (Latvijas Vēstnesis, 246), https://likumi.lv/ta/en/en/id/225418the-civil-law. Pristupljeno 19. lipnja 2020. 
4. Obiteljski zakon Estonije (Riigi Teataja, I 2009, 60, 395), s posljednjim izmjenama i dopunama (Riigi Teataja, I 2017, 1), https://www.riigiteataja.ee/en/eli/ee/507022018005/ consolide/current. Pristupljeno 18. lipnja 2020.

5. Obiteljski zakon iz 2015., Narodne novine RH, br. 103/2015, 98/2019, 47/2020 - v. čl. 35. Zakona o Centru za posebno skrbništvo.

6. Pravilnik o elektroničkom poslovanju korisnika i ovlaštenih korisnika sustava zemljišnih knjiga, Narodne novine RH, br. 108/2019.

7. Savezni zakon o sudskom postupku u izvanparničnim pravnim stvarima (Bundesgesetz über das gerichtliche Verfahren in Rechtsangelegenheiten außer Streitsachen, Außerstreitgesetz) od 13. studenog 2003. (BGBl I 2003/111), s posljednjim izmjenama i dopunama (BGBl I 2019/38), https://www. jusline.at/gesetz/aussstrg. Pristupljeno 24. lipnja 2020.

8. Uredba Vijeća (EU) 2019/1111 od 25. lipnja 2019. o nadležnosti, priznavanju i ovrsi odluka u bračnim predmetima i predmetima roditeljske odgovornosti, te o međunarodnoj otmici djece (preinaka), Službeni list EU-a, br. L 178/2019, str. 1.-115.

9. Zakon br. 1547 od 18. studenoga 2016. o modernizaciji pravosuđa u 21. stoljeću, https://www. legifrance.gouv.fr/affichLoiPreparation.do?idDocument=JORFDOLE000030962821\&type=general\&typeLoi=proj\&legislature=14. Pristupljeno 19. lipnja 2020.

10. Zakon br. 287/2009 - Građanski zakonik Rumunjske (Monitorul Oficial al României, 511/2009), s posljednjim izmjenama i dopunama (Zakon br. 71/2011, Monitorul Oficial al României, 427/2011, 489/2011), http://legislatie.just.ro/Public/DetaliiDocument/175630. Pristupljeno 19. lipnja 2020.

11. Zakon br. 4509/2017, čl. 22. (GG A 201, 22. prosinca 2017.), kojim su izmijenjeni čl. 1438. i čl. 1441. Građanskoga zakonika Grčke.

12. Zakon o nepravdnem postopku (ZNP-1), Uradni list RS, br. 16/2019, http://www.pisrs.si/Pis.web/ pregledPredpisa?id=ZAKO7879. Pristupljeno 24. lipnja 2020.

13. Zakon o notariatu (ZN), Uradni list RS, br. 2/2007 - službeni pročišćeni tekst, 33/2007 - Zakon o spremembah in dopolnitvah Zakona o sodnem registru (ZSReg-B), 45/2008, 91/2013, http://pisrs.si/ Pis.web/pregledPredpisa?id=ZAKO1329. Pristupljeno 25. lipnja 2020.

14. Zakon o notarima Estonije (Riigi Teataja, I 2000, 104, 684), nakon izmjena i dopuna (Riigi Teataja, I 2009, 27, 164), s posljednjim izmjenama i dopunama (Riigi Teataja, I 2019, 8), https://www.riigiteataja.ee/en/eli/ee/506012020001/consolide/current. Pristupljeno 18. lipnja 2020.

15. Zakon o notarima Latvije (Latvijas Vēstnesis, 48, 9. srpnja 1993.), s posljednjim izmjenama i dopunama od 14. studenog 2019. (Latvijas Vēstnesis, 240), https://likumi.lv/ta/en/en/id/59982. Pristupljeno 19. lipnja 2020.

16. Zakon o notarima Španjolske od 28. svibnja 1862., izmijenjen i dopunjen Zakonom br. 15/2015 o dobrovoljnoj sudbenosti od 2. srpnja 2015. (Boletín Oficial del Estado, br. 158/2015), http:// iuscomparatum.info/wp-content/uploads/2015/07/Boletin-Oficial-del-Estado-Viernes-3-de-juliode-2015.pdf. Pristupljeno 19. lipnja 2020.

17. Zakon o partnerski zvezi (ZPZ), Uradni list RS, br. 33/2016, http://www.pisrs.si/ Pis.web/pregledPredpisa?id=ZAKO7434. Pristupljeno 25. lipnja 2020.

18. Zakon o postupku u obiteljskim stvarima i stvarima dobrovoljne sudbenosti (Gesetz über das Verfahren in Familiensachen und in den Angelegenheiten der freiwilligen Gerichtsbarkeit) od 17. prosinca 2008. (BGBl I S 2586, 2587), s posljednjim izmjenama i dopunama (čl. 4. Zakona od 19. ožujka 2020., BGBl I S 541), https://www.gesetze-im-internet.de/famfg/BJNR258700008.html. Pristupljeno 24. lipnja 2020.

19. Zakon o pravdnem postopku (ZPP), Uradni list RS, br. 73/2007 - službeni pročišćeni tekst, 45/2008 - Zakon o arbitraži (ZArbit), 45/2008, 111/2008 - Odluka USRS, 57/2009 - Odluka USRS, 12/2010 
- Odluka USRS, 50/2010 - Odluka USRS, 107/2010 - Odluka USRS, 75/2012 - Odluka USRS, 40/2013 - Odluka USRS, 92/2013 - Odluka USRS, 10/2014 - Odluka USRS, 48/2015 - Odluka USRS, 6/2017 - Odluka USRS, 10/2017, 16/2019 - Zakon o nepravdnem postopku (ZNP-1), 70/2019 - odluka USRS, http://pisrs.si/Pis.web/pregledPredpisa?id=ZAKO1212. Pristupljeno 24. lipnja 2020.

20. Zakon o registraciji osobnih stanja Estonije (Riigi Teataja, I 2009, 30, 177), s posljednjim izmjenama i dopunama (Riigi Teataja, I 2019, 3), https://www.riigiteataja.ee/en/eli/ee/ 504022014001/ consolide/current. Pristupljeno 18. lipnja 2020.

21. Zakon o zakonski zvezi in družinskih razmerjih iz 1976., Uradni list RS, br. 69/2004 - službeni pročišćeni tekst, 101/2007 - Odluka USRS, 90/2011 - Odluka USRS, 84/2012 - Odluka USRS, 82/2015 - Odluka USRS, 15/2017 - Družinski zakonik (DZ), 30/2018 - Zakon o socialnem vključevanju invalidov (ZSVI), http://pisrs.si/Pis.web/pregledPredpisa?id =ZAKO40. Pristupljeno 24. lipnja 2020.

22. Zakon o zemljišnim knjigama, Narodne novine RH, br. 63/2019.

23. Zakon o životnom partnerstvu, Narodne novine RH, br. 92/2014, 98/2019.

\section{MREŽNI IZVORI}

1. Anthimos, A., Divorce in mutual consent before a notary public, 28. prosinca 2017., http://icl-ingreece.blogspot.com/2017_12_24_archive.html. Pristupljeno 23. lipnja 2020.

2. Baos, C., Divorce in Spain before a notary. Legal advice for expatriates. International Law, 2018., https://www.white-baos.com/en/divorce-in-spain-before-a-notary-legal-advice-for-expatriates-international-law.html. Pristupljeno 23. lipnja 2020.

3. Charakopoulou, D., Divorce, 5. ožujka 2019., http://www.greeklawdigest.gr/topics/aspects-ofgreek-civil-law/item/216-divorce. Pristupljeno 23. lipnja 2020.

4. Divorce France, Example of an amicable divorce agreement, 2017., https://www.divorcefrance.fr/ types-de-divorce/modele-de-convention-divorce-amiable/. Pristupljeno 23. lipnja 2020.

5. Eskenazi, D.; Brown, C.; Mitchell, I.; Morley, J. D., The New Divorce by Mutual Consent in France: Recognition and Risks of Post-Divorce Litigation in Common-Law Countries: The Examples of England and the United States, 2017., https://www.familylawweek.co. uk/site.aspx?i=ed177705. Pristupljeno 23. lipnja 2020.

6. Grant, E., Spanish notaries given power to grant divorce, 6. srpnja 2015., http://www.spanishbarrister. com/spanish-notaries-given-power-to-grant-divorce/. Pristupljeno 26. lipnja 2020.

7. Notaries of France, What procedure in case of a divorce in France?, 4. srpnja 2020., https://www.notaires.fr/en/couple-family/differents-types-divorce. Pristupljeno 23. lipnja 2020.

8. Rozou, A., Divorce by Mutual Consent in Greece, 29. veljače 2020., https://www.nomikosodigos.info/ en/articles/902-mutual-consent-divorce. Pristupljeno 23. lipnja 2020.

9. Spanish Solutions, Divorce at a Spanish Notary, 1. kolovoza 2017., https://www.spanishsolutions. net/blog/legal-issues-in-spain/new-law-it-is-now-sometimes-possible-to-divorce-at-a-spanish-notary-not-in-court/. Pristupljeno 23. lipnja 2020.

10. Višestruko povećan broj elektroničkih prijedloga za upis u zemljišne knjige, IUS-INFO, 4. ožujka 2020., http://www.iusinfo.hr/DailyContent/News.aspx?id=40813\#. Pristupljeno 26. lipnja 2020. 


\section{DIVORCE BEFORE A LATIN-TYPE NOTARY IN THE REFORMED SLOVENIAN LAW}

\section{Summary}

Divorce before Latin-type notaries, as an alternative to court procedure, has been present on the European continent since the early 2000s. Forms of such divorce first appeared in Eastern European countries. However, since 2015 there has been a regulation of the powers of notaries for consensual divorce in the countries of Western and Southern Europe. The last among European countries to prescribe the consensual divorce before notaries is Slovenia, as part of the reform of family and non-contentious law and procedure.

In this context, the paper discusses the novelties and basic principles of family court proceedings in the reformed Slovenian law. A special part of the paper contains an analysis of the consensual divorce before Slovenian notaries. The reason for choosing this legal system is the circumstance of the same starting point of development with Croatia, the similarity of these two legal systems, as well as the fact that in these Central European EU member states, reform efforts in one usually follow reforms and results in the other. Then follows an analysis and discussion of notarial divorce from a Croatian perspective, in particular on the circumstances that should be taken into account when considering its regulation, in order to reflect and achieve the prominent advantages. The concluding part of the paper contains some thoughts of the author and his de lege ferenda projections for the Croatian regulation, but also for the states in its neighbourhood.

Keywords: $\quad$ divorce, Latin-type notary, procedure, Slovenian law

\section{(c) (i) 8}

This work is licensed under a Creative Commons

Attribution-NonCommercial 4.0 International License.

Slađana Aras Kramar, PhD, Associate Professor, Faculty of Law, University of Zagreb, Trg Republike Hrvatske 14, 10000 Zagreb. E-mail address: sladana.aras@pravo.hr. ORCID: https://orcid.org/0000-0002-8908-775X. 